\title{
Potash Breakdown of Poly-Mineralized Niobium-Tantalum-Lanthanides Ore Material
}

\author{
Mona N. El Hazek ${ }^{1,2 *}{ }^{\oplus}$, Nawal H. Mohamed ${ }^{1,3}$, Azza A. Gabr ${ }^{1,4}$ \\ ${ }^{1}$ Chemistry Department, Faculty of Science, Jazan University, Jizan, Saudi Arabia \\ ${ }^{2}$ Nuclear Materials Authority, Cairo, Egypt \\ ${ }^{3}$ Desert Research Center, Cairo, Egypt \\ ${ }^{4}$ Chemistry Department, Faculty of Science, Aswan University, Aswan, Egypt \\ Email: ^monaelhazek4861@gmail.com
}

How to cite this paper: El Hazek, M.N., Mohamed, N.H. and Gabr, A.A. (2019) Potash Breakdown of Poly-Mineralized Niobium-Tantalum-Lanthanides Ore Material. American Journal of Analytical Chemistry, 10, 103-111.

https://doi.org/10.4236/ajac.2019.103009

Received: February 6, 2019

Accepted: March 11, 2019

Published: March 14, 2019

Copyright (c) 2019 by author(s) and Scientific Research Publishing Inc. This work is licensed under the Creative Commons Attribution International License (CC BY 4.0).

http://creativecommons.org/licenses/by/4.0/

\begin{abstract}
The potentiality of the alkali breakdown of the poly mineralized ore material south Gabal El-A'urf area, central Eastern Desert, Egypt is investigated. It includes the multiple oxide mineral tanteuxenite, monazite, bastnasite, anatase, as well as zircon. This ore material assaying lanthanides $\left(\mathrm{RE}_{2} \mathrm{O}_{3} 1.9 \%\right)$, niobium $\left(\mathrm{Nb}_{2} \mathrm{O}_{5} 1.25 \%\right)$ as well as titanium and zirconium $\left(\mathrm{TiO}_{2}\right.$ and $\mathrm{ZrO}_{2} 1.23 \%$ and $1.12 \%)$ respectively besides tantalum $\left(\mathrm{Ta}_{2} \mathrm{O}_{5} 0.13 \%\right)$, were used for the present work. This sample has thus been subjected to two alkali breakdown techniques using potash; namely agitation leaching and fusion. The latter technique was found to be preferred as it gives higher leaching efficiency. The optimum leaching conditions are weight ratio of the ore/potassium hydroxide $1 / 2$ at $400^{\circ} \mathrm{C}$ for $1 \mathrm{~h}$. The realized leaching efficiencies attained $95.0 \%$ and 93.7\% for $\mathrm{Nb}$ and $\mathrm{Ta}$ respectively as well as $96 \%$ for lanthanides and $75 \%$ for Ti while that for $\mathrm{Zr}$ did not exceed $10 \%$.
\end{abstract}

\section{Keywords}

Lkali Fusion, Agitation Leaching, Niobium-Tantalum-Lanthanides Ores, Polymineralized Ore Material

\section{Introduction}

A poly mineralized ore material from south Gabal El-A'urf area, central Eastern Desert, Egypt [1] includes several interesting minerals; namely tanteuxenite, monazite, bastnasite, anatase and zircon. The corresponding interesting rare metals of these minerals in a properly prepared technological sample for the present work include $\mathrm{RE}_{2} \mathrm{O}_{3} 1.9 \%, \mathrm{Nb}_{2} \mathrm{O}_{5} 1.25 \%$ as well as $\mathrm{TiO}_{2}$ and $\mathrm{ZrO}_{2} 1.23 \%$ 
and $1.12 \%$ respectively besides $\mathrm{Ta}_{2} \mathrm{O}_{5} 0.13 \%$. Several leaching studies have been performed upon comparable ore materials from different locations, but with different constituents and grades of the economic metal values. These studies include those of Shaw and Lindstrom [2] who reported that euxenite was recovered by fusing the ore material with $\left(\mathrm{NH}_{4}\right)_{2} \mathrm{SO}_{4}$ or $\left(\mathrm{NH}_{4}\right) \mathrm{HSO}_{4}$ at $400^{\circ} \mathrm{C}$ for 4 hours. Shaw [3] indicated that euxenite from Arizona is amenable to REE recovery by digestion with $\mathrm{HF}-\mathrm{H}_{2} \mathrm{SO}_{4}$ acid mixture. On the other hand, Shaw and Bauer [4] treated Idaho euxenite by $\mathrm{H}_{2} \mathrm{SO}_{4}$ acid alone for REE recovery. However, Pittuck et al. [5] performed a caustic fusion process for a concentrate of euxenite and fergusonite that assayed $9.4 \% \mathrm{U}_{3} \mathrm{O}_{8}$ and $12.4 \% \mathrm{Nb}_{2} \mathrm{O}_{5}$ at $700^{\circ} \mathrm{C}$ for $10-$ 15 min with an ore/reagent ratio of 1/3. Xiaohui Wang et al. [6] have also studied the leaching of $\mathrm{Nb}$ and $\mathrm{Ta}$ from a low-grade ore using $\mathrm{KOH}$ roast-water leach system. They achieved 95\% and 94\% leaching efficiencies for $\mathrm{Nb}$ and $\mathrm{Ta}$ with $80 \%$ for Si and Sn, $50 \%$ for Ti and $<20 \%$ for Fe and Mn. Silva et al., [7] investigated a Brazilian zircon concentrate fusion with $\mathrm{NaOH}$ followed by a two-step leaching. The effects of $\mathrm{NaOH}$ /zircon mass ratio, temperature and time were determined. The best fusion conditions were: $\mathrm{NaOH} / \mathrm{ZrSiO}_{4}$ mass ratio = 1.5:1; temperature, $575^{\circ} \mathrm{C}$; reaction time, $30 \mathrm{~min}$. Water leaching was best conducted with a water/fused mass ratio $=3.75$ at $25^{\circ} \mathrm{C}$. Acid leaching required $100 \mathrm{~mL} 3 \mathrm{~mol} \cdot \mathrm{L}^{-1} \mathrm{H}_{2} \mathrm{SO}_{4} \mathrm{~g}^{-1}$ water-insoluble solid at $25^{\circ} \mathrm{C} .97 \mathrm{wt} \%$ of $\mathrm{ZrSiO}_{4}$ was decomposed and around $91.5 \mathrm{wt} \%$ of $\mathrm{Zr}$ was recovered in the final product.

Concerning local ore materials, El Hazek [8] has studied the recovery of valuable metals from polymineralized ore material containing samarskite, betafite, thorite, uranophane and zircon. The ore concentrate assayed $31.77 \% \mathrm{RE}_{2} \mathrm{O}_{3}$, 20.78\% $\mathrm{Nb}_{2} \mathrm{O}_{5}, 9.09 \% \mathrm{ZrO}_{2}, 6.45 \% \mathrm{ThO}_{2}, 2.2 \% \mathrm{U}_{3} \mathrm{O}_{8}$ and only $1.06 \% \mathrm{Ta}_{2} \mathrm{O}_{5}$ as well as $0.33 \% \mathrm{TiO}_{2}$. This ore material was subjected to $\mathrm{H}_{2} \mathrm{SO}_{4}$ agitation leaching to dissolve $\mathrm{U}$, Th and REE while keeping $\mathrm{Nb}, \mathrm{Ta}, \mathrm{Ti}$ and $\mathrm{Zr}$ in the residue for subsequent leaching by HF. El Hussaini and Mahdy [9] have also studied the recovery of valuable metals from ore material containing fergusonite and euxenite besides the refractory $\mathrm{U}$ mineral davidite. Using $\mathrm{H}_{2} \mathrm{SO}_{4} / \mathrm{HNO}_{3}$ acid mixture agitation leaching, almost complete dissolution of $\mathrm{Nb}$ and $\mathrm{Ta}$ was achieved together with $86 \%$ of $\mathrm{Th}$ and $70 \%$ of the REE; however, $\mathrm{U}$ and Ti leaching efficiencies did not exceed $60 \%$. On the other hand, El Hazek et al. [10] have applied different breakdown techniques including agitation with conc. $\mathrm{H}_{2} \mathrm{SO}_{4}$ and potassium bisulfate fusion upon a polymineralized material to dissolve its metal values. The latter technique has realized maximum leaching efficiencies for all the metal values where $\mathrm{Nb}$ and $\mathrm{Ta}$ attained $98 \%$ and $99.3 \%$ as well as complete dissolution for REE and $94 \%$ for Ti while that of Zr didn't exceed $20 \%$. The relevant optimum fusion conditions were $1 / 3$ as the ore/reagent ratio at $650^{\circ} \mathrm{C}$ for $3 \mathrm{~h}$.

In the light of these givings, the present work was so planned to study the potentiality of potash breakdown of these minerals either by agitation or fusion at relatively high temperature. For this purpose, several experiments have been performed in both techniques to attain the optimum conditions that achieve highest dissolution with least cost. 


\section{Experimental}

\subsection{Analytical Procedures}

The ore material from south Gabal El-A'urf area, central Eastern Desert, Egypt is subjected to complete chemical analysis for both major oxides and the economic metal values. Representative sample portions of the collected sample were properly obtained by proper quartering of the working sample after its grinding to -200 mesh size ( $-65 \mathrm{um}$ ). The major oxides have been analyzed using Shapiro and Brannock [11] rapid silicate analytical procedure. For $\mathrm{Ca}$ and $\mathrm{Mg}$, a titrimetic method with EDTA using Eriochrome black $\mathrm{T}$ and Murexide as indicators was used [12]. The spectrometric analysis was used for $\mathrm{SiO}_{2}, \mathrm{Al}_{2} \mathrm{O}_{3}$, and $\mathrm{Fe}_{2} \mathrm{O}_{3}$ (total) [11] [12], while for $\mathrm{Na}_{2} \mathrm{O}$ and $\mathrm{K}_{2} \mathrm{O}$, flame photometry was applied using JENWAY flame photometer. The total loss of ignition (obtained at $1000^{\circ} \mathrm{C}$ ) is corresponding to humidity, combined water, $\mathrm{CO}_{2}$ as well as possible organic matter [11].

On the other hand, the total REEs content was analyzed by a UV-Visible Spectrophotometer model Shimadzu UV-160A using Arsenazo III at wavelength $650 \mathrm{~nm}$ Marczenko [13]. The other metal values $\mathrm{Ti}, \mathrm{Nb}, \mathrm{Ta}$ and $\mathrm{Zr}$ were analyzed by the atomic absorption technique using a Unicam model 969 auto gas box at the wavelengths $365.4 \mathrm{~nm}, 334.4 \mathrm{~nm}, 271.5 \mathrm{~nm}$ and $360.1 \mathrm{~nm}$ respectivly Weltz and Sperling [14].

\subsection{Alkali Breakdown Procedures}

In both studied techniques, all the experiments have been performed using sample portions of the ground ore material. The interesting factors affecting both potash agitation leaching and potash fusion techniques have been examined.

\section{1) $\mathrm{KOH}$ agitation leaching}

Each leaching experiment has been performed by agitating a weighed amount of the ground ore sample with the alkali using different concentrations with different solid/liquid ratios for different periods of time at different temperature degrees. In these experiments, a hot plate fitted with a magnetic stirrer was used and the required precautions were taken to avoid evaporation. For high temperature degrees, an oil bath was used. At the end of each experiment, the obtained slurry was cooled, filtered, washed with distilled water and made up to volume. The obtained solution is then analyzed for the different metal values $(\mathrm{Nb}, \mathrm{Ta}$, $\mathrm{REE}, \mathrm{Ti}$ and $\mathrm{Zr}$ ) to calculate the leaching efficiency percent according to the equation:

$$
\% \text { leaching efficiency }=\frac{\text { Metal content in the leach solution }}{\text { Original metal content in the ore sample }} \times 100
$$

\section{2) $\mathrm{KOH}$ fusion}

Several fusion experiments have been performed using different amounts of $\mathrm{KOH}$ which were mixed with the sample portions in porcelain crucibles and heated in a muffle furnace for different periods of time at different temperature 
degrees. The obtained melt was then cooled and leached with distilled water, while the remaining ore residue was filtered and properly washed while the filtrate and washings were made up to volume for analyzing the interesting metal values for calculating their leaching efficiency percent.

\section{Results and Discussion}

\subsection{Ore Composition}

The results of the complete chemical analysis of the working technological ore material is shown in Table 1 where it is clearly evident that it is mainly composed of $\mathrm{SiO}_{2}$ besides $\mathrm{Al}_{2} \mathrm{O}_{3}$ and $\mathrm{Fe}_{2} \mathrm{O}_{3}$. The relatively high $\mathrm{K}_{2} \mathrm{O}$ content (4.92\%) is indeed due to K-metasomatism while $\mathrm{Na}$ is markedly depleted (2.13\%). On the other hand, the assay of the economic rare metal values including $\mathrm{U}$ (100 ppm) and $\mathrm{Th}(40 \mathrm{ppm})$ can be increased by some conventional physical techniques.

\subsection{Result of Alkali Breakdown Techniques}

\section{1) $\mathrm{KOH}$ agitation leaching}

a) Effect of $\mathrm{KOH}$ concentration

This factor was studied using different concentrations of $\mathrm{KOH}$ ranging from 6 to $12 \mathrm{M}$ while the other leaching conditions were fixed at $200^{\circ} \mathrm{C}$ for $3 \mathrm{~h}$ with a $\mathrm{S} / \mathrm{L}$ ratio of $1 / 2$. The obtained leaching efficiencies (Table 2) show that $\mathrm{Nb}$ and Ta dissolution increased from $81.0 \%$ to $87.5 \%$ and from $80.0 \%$ to $85.0 \%$ respectively whereas REE and Ti dissolution increased from $81.0 \%$ to $89.0 \%$ and from $73.0 \%$ to $79.0 \%$ respectively by increasing the alkali conc. from 8 to $10 \mathrm{M}$. Further increase in alkali concentration to $12 \mathrm{M}$ keeps comparable results for all metals leaching efficiencies. However, Zr leaching efficiency didn't exceeds 9\% as it requires a temp. higher than $200^{\circ} \mathrm{C}$.

Table 1. Chemical composition of the ore material.

\begin{tabular}{cccc}
\hline Major constituent & $\mathrm{Wt} \%$ & trace constituent & $\mathrm{Wt} \%$ \\
\hline $\mathrm{SiO}_{2}$ & 74.00 & $\mathrm{RE}_{2} \mathrm{O}_{3}$ & 1.90 \\
$\mathrm{TiO}_{2}$ & 1.23 & $\mathrm{Nb}_{2} \mathrm{O}_{5}$ & 1.25 \\
$\mathrm{Al}_{2} \mathrm{O}_{3}$ & 5.00 & $\mathrm{Ta}_{2} \mathrm{O}_{5}$ & 0.13 \\
$\mathrm{Fe}_{2} \mathrm{O}_{3}$ & 5.10 & $\mathrm{ZrO}_{2}$ & 1.12 \\
$\mathrm{CaO}$ & 1.64 & $\mathrm{U}_{3} \mathrm{O}_{8}$ & 0.01 \\
$\mathrm{MgO}$ & 0.80 & $\mathrm{ThO}_{2}$ & 0.04 \\
$\mathrm{MnO}$ & 0.05 & & \\
$\mathrm{Na}_{2} \mathrm{O}$ & 2.03 & & \\
$\mathrm{~K}_{2} \mathrm{O}$ & 4.90 & & \\
$\mathrm{P}_{2} \mathrm{O}_{5}$ & 0.06 & & \\
$\mathrm{LOI}^{*}$ & 0.74 & & \\
& & & \\
\end{tabular}

LOI* includes $\mathrm{H}_{2} \mathrm{O}^{\text {crystalline }}$ and $\mathrm{CO}_{2}$. 
Table 2. Effect of $\mathrm{KOH}$ conc. on the leaching efficiencies of the metal values.

\begin{tabular}{cccccc}
\hline \multirow{2}{*}{ Conc. KOH, M } & \multicolumn{5}{c}{ Leaching efficiency, \% } \\
\cline { 2 - 6 } & $\mathrm{Nb}$ & $\mathrm{Ta}$ & $\mathrm{REE}$ & $\mathrm{Ti}$ & $\mathrm{Zr}$ \\
\hline 6 & 72 & 73 & 75 & 66 & 5 \\
8 & 81 & 80 & 81 & 73 & 6 \\
10 & 87.5 & 85 & 89 & 79 & 9 \\
12 & 87 & 84 & 86 & 74 & 9 \\
\hline
\end{tabular}

b) Effect of solid/liquid ratio (S/L)

The effect of the S/L ratio (ore weight/KOH solution ratio) upon the leaching efficiency of the interesting metals was studied with ratios ranging from $1 / 1$ to $1 / 3$ using $10 \mathrm{M} \mathrm{KOH}$ at $200^{\circ} \mathrm{C}$ for $3 \mathrm{~h}$. The leaching efficiencies (Table 3 ) indicate that at $1 / 2 \mathrm{~S} / \mathrm{L}$ ratio, the leaching efficiencies for $\mathrm{Nb}$ and $\mathrm{Ta}$ were $87.5 \%$ and $85 \%$ respectively together with $89 \%$ and $79 \%$ for REE and Ti whilst $\mathrm{Zr}$ leaching efficiency didn't exceed 9\%. The realized leaching efficiencies have almost been kept steady at the $\mathrm{S} / \mathrm{L}$ ratio of $1 / 3$.

c) Effect of leaching temperature

This factor was studied in the range from 80 up to $240^{\circ} \mathrm{C}$ while the other conditions were fixed at $10 \mathrm{M} \mathrm{KOH}$ conc., a S/L ratio of $1 / 2$ and a leaching time of $3 \mathrm{~h}$. The obtained data (Table 4 ) indicate that the working polymineralized ore material requires a relatively high temp. to be broken due to its refractory nature. However, the leaching efficiencies for all the study metal values (except $\mathrm{Zr}$ ) increased sharply by increasing the temp. till $200^{\circ} \mathrm{C}$ where the leaching efficiencies for $\mathrm{Nb}$ and $\mathrm{Ta}$ attained $87.5 \%$ and $85 \%$ while REE and Ti leaching efficiencies attained $89 \%$ and $79 \%$ while the $\mathrm{Zr}$ leaching efficiency attained only $9 \%$. Further increase in temperature beyond $200^{\circ} \mathrm{C}$ was found to have an adverse effect.

d) Effect of leaching time

The effect of leaching time was studied in the range of 1 to $4 \mathrm{~h}$ while the other leaching conditions were fixed at $10 \mathrm{M} \mathrm{KOH}$ conc., S/L ratio of $1 / 2$ at $200^{\circ} \mathrm{C}$. The corresponding leaching efficiencies (Table 5) of $\mathrm{Nb}$ and $\mathrm{Ta}$ attained $69.0 \%$ and $68.0 \%$ at $1 \mathrm{~h}$ and extending the leaching time up to $3 \mathrm{~h}$ increased these values up to $87.5 \%$ and $85 \%$ respectively. The leaching efficiencies of the lanthanides and $\mathrm{Ti}$ at this leaching time attained $89.0 \%$ and $79.0 \%$. On the other hand, the $\mathrm{Zr}$ leaching efficiency was only $9 \%$. Extending the leaching time for $4 \mathrm{~h}$ was found to have an adverse effect upon the dissolution of Nb, Ta, REEs and Ti.

\section{2) $\mathrm{KOH}$ fusion}

\section{a) Effect of ore/ $\mathrm{KOH}$ ratio (O/R ratio)}

A set of alkali fusion experiments using potash has been performed using different $\mathrm{O} / \mathrm{R}$ weight ratios ranging from 1:1 to 1:4 while the other two fusion conditions were fixed at $400^{\circ} \mathrm{C}$ for $1 \mathrm{~h}$. The results shown in Table 6 proved that the leaching efficiencies of the interesting metals have been markedly increased at $1 / 2$ ore/KOH ratio up to about $94 \%$ or more for $\mathrm{Nb}$, Ta \& REEs and to $75 \%$ and 
Table 3. Effect of S/L ratio on the leaching efficiencies of the metal values.

\begin{tabular}{cccccc}
\hline \multirow{2}{*}{ S/L ratio } & \multicolumn{5}{c}{ Leaching efficiency, \% } \\
\cline { 2 - 6 } & $\mathrm{Nb}$ & $\mathrm{Ta}$ & $\mathrm{REE}$ & $\mathrm{Ti}$ & $\mathrm{Zr}$ \\
\hline $1 / 1$ & 79 & 75 & 80 & 71 & 6 \\
$1 / 2$ & 87.5 & 85 & 89 & 79 & 9 \\
$1 / 3$ & 85.5 & 84 & 88 & 77 & 9 \\
\hline
\end{tabular}

Table 4. Effect of temp. on the leaching efficiencies of the metal values.

\begin{tabular}{cccccc}
\hline \multirow{2}{*}{ Temp., ${ }^{\circ} \mathrm{C}$} & \multicolumn{5}{c}{ Leaching efficiency, \% } \\
\cline { 2 - 6 } & $\mathrm{Nb}$ & $\mathrm{Ta}$ & $\mathrm{REE}$ & $\mathrm{Ti}$ & $\mathrm{Zr}$ \\
\hline 80 & 64 & 61 & 64 & 69 & 4 \\
120 & 70 & 71 & 70 & 72 & 5 \\
160 & 80 & 80 & 82 & 77 & 8 \\
200 & 87.5 & 85 & 89 & 79 & 9 \\
240 & 77 & 79 & 87 & 72 & 10 \\
\hline
\end{tabular}

Table 5. Effect of time on the leaching efficiencies of the metal values.

\begin{tabular}{cccccc}
\hline \multirow{2}{*}{ Time, h } & \multicolumn{5}{c}{ Leaching efficiency, \% } \\
\cline { 2 - 6 } & $\mathrm{Nb}$ & $\mathrm{Ta}$ & $\mathrm{REE}$ & $\mathrm{Ti}$ & $\mathrm{Zr}$ \\
\hline 1 & 69 & 68 & 68 & 60.5 & 5 \\
2 & 80 & 79 & 81 & 70.5 & 7 \\
3 & 87.5 & 85 & 89 & 79 & 9 \\
4 & 84 & 82 & 87 & 78 & 9 \\
\hline
\end{tabular}

Table 6. Effect of $\mathrm{O} / \mathrm{R}$ ratio on the leaching efficiencies of the metal values.

\begin{tabular}{cccccc}
\hline \multirow{2}{*}{ O/R ratio } & \multicolumn{5}{c}{ Leaching efficiency, \% } \\
\cline { 2 - 6 } & $\mathrm{Nb}$ & $\mathrm{Ta}$ & $\mathrm{REE}$ & $\mathrm{Ti}$ & $\mathrm{Zr}$ \\
\hline $1 / 1$ & 72.1 & 70.5 & 78 & 61.5 & 5 \\
$1 / 2$ & 95.0 & 93.7 & 96 & 75 & 10 \\
$1 / 3$ & 90.2 & 88 & 91 & 71 & 10 \\
$1 / 4$ & 88.8 & 82 & 87 & 68.2 & 9.5 \\
\hline
\end{tabular}

$10 \%$ for $\mathrm{Ti} \& \mathrm{Zr}$ respectively. Increasing the S/R ratio beyond $1 / 2$ has progressively decreased the leaching efficiencies for all the study metals; a matter which is most probably due to hydrolysis.

b) Effect of fusion temperature

A second series of alkali fusion experiments has been carried out at temp. ranging from $300^{\circ} \mathrm{C}$ to $600^{\circ} \mathrm{C}$ while the other fusion conditions were fixed at an ore/ $\mathrm{KOH}$ ratio of $1: 2$ for $1 \mathrm{~h}$. The obtained leaching efficiencies of the study 
metals, Table 7 were found to increase gradually by raising the fusion temp. from $300^{\circ} \mathrm{C}$ to $400^{\circ} \mathrm{C}$ where they attained about $94 \%$ or more for $\mathrm{Nb}$, Ta \& REEs and $75 \%$ for Ti whereas only $10 \%$ for Zr. However, increasing the fusion temperature to $500^{\circ} \mathrm{C}$ and $600^{\circ} \mathrm{C}$ has an adverse effect on the leaching efficiencies of these metal values that might be due to hydrolysis. On the other hand, the leaching efficiency of $\mathrm{Zr}$ was markedly improved by increasing the fusion temp. where it attained $24.5 \%$ at $500^{\circ} \mathrm{C}$ and $36.0 \%$ at $600^{\circ} \mathrm{C}$. This is most probably due to the refractory nature of the zircon mineral.

c) Effect of fusion time

A third set of alkali fusion experiments was performed for time periods ranging from 30 to $120 \mathrm{~min}$. while the other fusion conditions were fixed at an ore/ $\mathrm{KOH}$ ratio of $1: 2$ and a fusion temperature of $400^{\circ} \mathrm{C}$. From the leaching efficiencies of the studied interesting metal values (Table 8), it is clearly evident that increasing the fusion time from 30 to $60 \mathrm{~min}$. increases the leaching efficiencies for all metals to become $96.0 \%$ and $93.7 \%$ for REE and Ta respectively and $95.0 \%$ and $75.0 \%$ for $\mathrm{Nb}$ and $\mathrm{Ti}$ respectively together with only $10 \%$ for Zr. Further increasing the fusion time to 90 and 120 min didn't improve the leaching efficiencies already obtained at $60 \mathrm{~min}$. for all the studied metal values.

\section{Conclusion}

The polymineralized ore material (real sample obtained from south Gabal El-A'urf area, central Eastern Desert, Egypt) has been subjected to two alkali breakdown techniques using potash; namely agitation leaching and fusion. Since alkali breakdown is highly selective and due to the refractory nature of this polymetallic ore material, sever conditions are necessary. In both techniques the

Table 7. Effect of the fusion temp. on the leaching efficiencies of the metal values.

\begin{tabular}{cccccc}
\hline \multirow{2}{*}{$\begin{array}{c}\text { Alkali fusion } \\
\text { temp., }\end{array}$} & \multicolumn{5}{c}{ Leaching efficiency, \% } \\
\cline { 2 - 6 } & $\mathrm{Nb}$ & $\mathrm{Ta}$ & $\mathrm{REE}$ & $\mathrm{Ti}$ & $\mathrm{Zr}$ \\
\hline 300 & 82 & 81 & 84 & 68 & 8 \\
400 & 95 & 93.7 & 96 & 75 & 10 \\
500 & 74.1 & 77 & 69 & 55 & 24.5 \\
600 & 72 & 71 & 70 & 52 & 36 \\
\hline
\end{tabular}

Table 8. Effect of the fusion time on the leaching efficiencies of the metal values.

\begin{tabular}{cccccc}
\hline \multirow{2}{*}{ Time, min } & \multicolumn{5}{c}{ Leaching efficiency, \% } \\
\cline { 2 - 6 } & $\mathrm{Nb}$ & $\mathrm{Ta}$ & $\mathrm{REE}$ & $\mathrm{Ti}$ & $\mathrm{Zr}$ \\
\hline 30 & 77 & 73 & 80 & 66 & 6 \\
60 & 95 & 93.7 & 96 & 75 & 10 \\
90 & 94 & 93.5 & 96 & 74.7 & 10 \\
120 & 95 & 93.5 & 95 & 74 & 10 \\
\hline
\end{tabular}


relevant conditions have been studied and optimized. Accordingly, for the agitation leaching, the determined optimum conditions involve $10 \mathrm{M}$ alkali concentration with a solid/liquid ratio of $1 / 2$ at $200^{\circ} \mathrm{C}$ for $3 \mathrm{~h}$ using an ore size up to -60 mesh. Under these conditions, it was possible to achieve leaching efficiencies of $87.5 \%$ and $85.0 \%$ for $\mathrm{Nb}$ and $\mathrm{Ta}$ respectively together with $89.0 \%$ and 79.0\% for REEs and Ti respectively while that of Zr didn't exceed 9\% due to refractory zircon mineral. On the other hand, for the preferable alkali fusion technique, the optimum conditions involve a weight ratio of ore/potassium hydroxide of $1 / 2$ at $400^{\circ} \mathrm{C}$ for $1 \mathrm{~h}$. The realized leaching efficiencies for the metal values have been attained $95.0 \%$ and $93.7 \%$ for $\mathrm{Nb}$ and Ta respectively as well as $96 \%$ for lanthanides and $75 \%$ for $\mathrm{Ti}$ while the leaching efficiency of $\mathrm{Zr}$ did not exceed $10 \%$ and hence would be concentrated in the residue left behind.

\section{Conflicts of Interest}

The authors declare no conflicts of interest regarding the publication of this paper.

\section{References}

[1] Abd El Ghani, I.M. (2000) Geology, Petrology and Radioactivity of G. El-A'urf Area, Central Eastern Desert, Egypt. Ph.D. Thesis, Faculty of Science, South Valley University, Qena.

[2] Shaw, V.E. and Lindstrom, R.E. (1967) Extraction of Euxenite Metal Values by Fusion with Ammonium Bisulfate or Ammonium Sulfate. U.S. Bureau of Mines, RI 6906.

[3] Shaw, V.E. (1959) Extraction of Rare Earth Elements from Bastanasite Concentrate. US Department of Interior, US Bureau of Mines RI 5474, Washington DC.

[4] Shaw, V.E. and Bauer, D.J. (1959) Extraction and Separation of Rare Earth Elements in Idaho Euxenite Concentrate. US Department of Interior, US Bureau Mines RI 6577, Washington DC.

[5] Pittuck, A.D., Freitag, C.A. and Lord, T.V. (1958) The Canadian Mining and Metallurgical Bulletin.

[6] Wang, X.H., Zheng, S.L., Xu, H.B. and Zhang, Y. (2009) Leaching of Niobium and Tantalum from a Low-Grade Ore Using a $\mathrm{KOH}$ Roast-Water Leach System. Hydrometallurgy, 93, 219-223. https://doi.org/10.1016/j.hydromet.2009.05.002

[7] da Silva, R.J.F., Dutra, A.J.B. and Afonso, J.C. (2012) Alkali Fusion Followed by a Two-Step Leaching of a Brazilian Zircon Concentrate. Hydrometallurgy, 117-118, 93-100

[8] El Hazek, M.N. (2001) Recovery of Uranium, Niobium and Tantalum from Kadabora Uraniferous Pegmatites, Eastern Desert, Egypt. Ph.D. Thesis, Faculty of Science, Ain Shams University, Cairo.

[9] El Hussaini, O.M. and Mahdy, M.A. (2002) Sulfuric Acid Leaching of Kab Amiri Nb-Ta Bearing Minerals, Central Eastern Desert, Egypt. Hydrometallurgy, 64, 219-229. https://doi.org/10.1016/S0304-386X(02)00045-2

[10] El Hazek, M.N., Amer, T.E., Abu El-Azm, M.G., Issa, R.M., Omar, S.A. and El-Hady, S.M. (2010) Characterization and Breakdown of South Gabal El A'urf Polymineralized Ore Material. Eurasian Chemico-Technological Journal, 35, 196-204. 
[11] Shapiro, I. and Brannock, W.W. (1962) Rapid Analysis of Silicate, Carbonate and Phosphate Rocks. Vol. 114 A, United States Government Printing Office, Washington DC.

[12] Jeffery, G.H., Bassett, J., Mendham, J. and Denney, R.C. (1989) Vogel's Textbook of Quantitative Chemical Analysis. 5th Edition, Longman Scientific and Technical, Wiley, New York.

[13] Marczenko, Z. (1986) Separation and Spectophotometric Determination of Elements. Ellis Hrwood Ltd. Pupl., New York.

[14] Welz, B. and Sperling, M. (1999) Atomic Absorption Spectrometry. 3rd Edition, Wiley-VCH, Weinheim, New York. 